Geliș Tarihi: 20.03.2019

Kabul Tarihi: 27.09.2019
Mediterranean Journal of Humanities mjh.akdeniz.edu.tr IX/2 (2019) 559-571

\title{
Gazipaşa Evleri
}

\section{Gazipaşa Houses}

\begin{abstract}
Nisa YILMAZ ERKOVAN * Nacide ÖTER **

$\ddot{O} z$ : Antalya'nın Gazipaşa İlçesi yüzyıllar boyu toplumlara ev sahipliği yapmış ve yerleşim görmüş bir ilçedir. Bu çalışmada, Gazipaşa yöresi geleneksel ev mimarisi hem plan yönünden hem de bu evlerin oluşumuna etki eden yöresel, kültürel, ekonomik, coğrafi ve inanç gibi çeşitli değişkenler düşünülerek ele alınmıştır. Çalışmada, Gazipaşa İlçesinde bulunan tescilli ve tescilsiz geleneksel yapıda konutlar ve bunlardan kırsal ve merkezde görece nitelikli olanlar seçilerek, ilçe merkezinde beş, kırsal bölge olan Hasdere'de beş adet konutun plan, malzeme, yapım tekniği, cepheleri incelenmiştir. Yapıların plan tipolojileri çıkarılmış, fotoğraflanarak belgelenmiş̧ir. Bu çalışmada, Gazipaşa evlerinin geleneksel konut mimarisi tipolojileri içerisindeki yeri araştırılmıştır. Yörede yer alan evlerin birçoğunun bu bölgede yaşamış insanların sosyal statüsü ve ekonomik durumlarına göre büyüklüklerinin de değiştiği izlenmektedir. Gazipaşa evlerinin ana malzemesini taş ve ahşap oluşturmaktadır. Taş, ahşap hatıllarla birlikte temel ve ana gövdeyi oluşturmaktadır. Oda ve sofalardan oluşan plan öğelerini tüm geleneksel yapılarda olduğu gibi planı şemasını iklim, topoğrafya, kültür, ekonomik yapı şekillendirmektedir. Birçoğu 19. yüzyıla ait olan tarihi bir vesika değerinde olan bu evlerin belgelenmesi ve gelecek nesillere aktarılması kültür mirasımız açısından önemlidir.
\end{abstract}

\section{Anahtar sözcükler: Gazipaşa, Geleneksel Yapı, Kırsal Mimari, Konut}

Abstract: Antalya/Gazipaşa is a district that has hosted settlements for centuries. In this study, the traditional building architecture of the Gazipaşa region has been studied considering various variables such as: the regional, cultural, economic, geographical and religious influence upon both the plan and the building of these houses. In this study, the traditional, registered and unregistered houses in Gazipaşa district and the relatively qualified ones in rural and central areas were selected, the plan, materials, construction techniques and facades of five houses in the district center and five houses in rural Hasdere were examined. In this study, the place of Gazipaşa houses in the typologies of traditional residential architecture was investigated. It was observed that many of the houses in the region are different in size according to the social status and the economic conditions of the people who lived in this region. The main materials of Gazipaşa houses are stone and wood. Stone, along with wooden beams, form the base and main body. The plan elements consisting of rooms and sofas are shaped by the plan, climate, topography, culture and economic structure, as are all traditional buildings. The documentation of these houses, many of which belong to the $19^{\text {th }} \mathrm{c}$. and their protection for future generations are important for our cultural heritage.

Keywords: Gazipaşa, Traditional Construction, Rural Architecture, House

\footnotetext{
* Dr. Öğr. Ü., Alanya Alaaddin Keykubat Üniversitesi, Sanat ve Tasarım ve Mim.Fak. Mimarlık Bölümü, Alanya Antalya. nisa.erkovan@alanya.edu.tr, https://orcid.org/0000-0002-7473-7131.

** Dr. Öğr. Ü., Alanya Alaaddin Keykubat Üniversitesi, Turizm Fakültesi, Turizm Rehberliği Bölümü Alanya Antalya.nacide.oter@alanya.edu.tr, https://orcid.org/0000-0002-0110-8246
} 


\section{Giriş}

Anadolu coğrafyasında Neolitik Çağ'a kadar giden zengin bir konut mimarisi çeşitliliği bulunmaktadır. Geçmişten günümüze kadar süregelen barınma ihtiyacı karşısında iklim, topoğrafya, malzeme, yapım tekniği, ekonomi, bitki örtüsü gibi fiziksel nedenler ile inanç, mahremiyet gibi sosyal, kültürel nedenler konut planlarının günümüze kadar çeşitlenmesine neden olmuştur. Kimi zaman yöredeki mevcut yapı ve yapım tekniklerinden kimi zamanda göçerlerin ve yakın kültürlerin etkisinde kalınmıştır. Bu ihtiyaçlar Güneydoğuda taş yapı geleneği, Orta Anadolu'da kerpiç, Kuzey bölgelerde ahşap, güneyde ise taş ve ahşap birlikteliği ile giderilmiştir. Ülkemizde konut mimarisindeki tarihsel sürekliliğe bakıldığında Türklerin Asya'dan bu yana hareketli oldukları dönemlerde geliştirdikleri "yaşama mekânları" ile karşılaşılmaktadır (Küçükerman \& Güner 1995, 25-26). Göçebe kültürün temel barınma öğesi ve yaşama mekânları olarak nitelendirilen çadırların şeklini ve mekânsal tasarımını doğa ile bütünleşmiş dışa açık hayat tarzı ve sıkı/yoğun toplum içi ilişkiler belirlemiştir (Köse 2005, 175). Konargöçer yaşam şekli zamanla yerini yerleşik düzene bırakmaya başlayınca doğal malzemeler çevreye uyumlu olarak bir mekânsal kurgu ile bir araya getirilerek barınma sorunu giderilmiştir. Bu geçiş ile çadırdaki mekânsal düzen fiziksel olarak ev planına aktarılmıştır. Bu planın ilk şekli tek odalı sofasız ev olarak belirtilmiştir. Bu ev planında çadır aynen odaya dönüşmüş, çadır önünün fonksiyonu tek odanın açıldığı avluya aktarılmıştır (Köse 2005, 175). Mekândaki hareketliliklerinden dolayı değişik kültürler ve yeni coğrafyalar ile yakın etkileşim halinde gelişen Türklerin mimarisini tekil ve doğrusal bir gelişim kalıbına oturtarak etkileşim halinde oldukları kültürlerin ve coğrafyaların katkılarından bağımsız olarak düşünmek de mümkün değildir (Kavas 2012, 506). Göçtükleri yerlerdeki kültürlerle etkileşim içerisinde olan konargöçer kültüre sahip bu insanlar için yerleşilen yerin yaşamlarını kolaylaştırması ve fonksiyonel olması oldukça önemlidir. Göçer veya yerleşik özelliklerinden bağımsız olarak mekân kurgusunun belirleyicileri işlevsel şema olduğu kadar temin edilebilen yapı malzemeleri ve bunların inşa için taşıdığı potansiyeldir. Mekân kurgusu doğrudan fiziksel kurguya, bir başka değişle, yapı malzemelerinin potansiyellerine ve yapısal bir bütünlük oluşturmak üzere bir araya geliş biçimlerine bağlıdır (Kavas 2012, 521). Göçebe çadırlarında keçe, keçi kılı, Orta Anadolu konutlarında kerpiç, güneyde taş ve ahşap yapı malzemelerinin kullanılması bu savı desteklemektedir. Anadolu'da zaten var olan yerleşik kültürlerin eskiden beri kullandıkları konut biçimleri ile göçebe/yarı göçebe kültürlerin sentezi ile kırsal yapı kültürü oluşmuştur. Anadolu'da konut mimarisi, ait olduğu toplumun kültürel bakış açısının dışa yansımasıdır. Toplumdan topluma değişen bu mimari, yöreden yöreye de değişim göstererek zaman içerisinde "geleneksel" sıfatını kazanmıştır. Geleneksel çevrenin kültürel olarak yorumlanması, genellikle yapı sahiplerinin, yapı ustası, marangoz ve taş ustası ile birlikte katılımı ile oluşması günlük yaşam ihtiyaçlarını karşılayan bir yapıya dönüşmesi bu türden yapıların en temel özelliğidir. Doğal malzemelerin işlevsel ihtiyaçlar sonucu belirli bir kurguyla bir araya gelmesiyle oluşan ev, geleneksel kent görüntüsünün en temel biçimidir (Kuban 2017, 1). Yapı ve çevrenin etkileşimini anlamak, yaşamın sürdürülmesi yanında yaşam kalitesi açısından da önemlidir. Geleneksel çevrede bu türden çok çeşitli örnekler bulunmaktadır ve yapılan ev ile insan kendisine özgü ayrıntıda toplum içindeki sürekliliğini sağlama bağlamak ister (Aran 2000, 48). Tüm bu olgularla birlikte yerleşim yerlerindeki nüfusun artması, din, kültür, sosyal yapılanma gibi kavramların gelişmesi geleneksel konut planlamasına da yansımıştır. Açık olan avlular kapanmaya, kapalı mekân sayıları artmaya ve dışa dönük konut yapısı giderek içe dönük bir hayat biçimine dönüşmeye başlamıştır. Bunun yaşama mekânındaki yansıması ise önce avlu biriminin belirginleştirilmesi, daha sonra yaşama birimlerini daraltılması ve birbirine yaklaştırılması, en sonunda sofa biriminin yaratılması şeklinde olmuştur. (Köse, 2005, 184). Fakat günümüzde Anadolu'nun birçok bölgesinde hala yarı göçer şekilde mevsimlik olarak tarım veya hayvancılıkla uğraşan kırsal yöre insanı farklı yerlere göç ederek ikincil bir konut veya geçici barınma 
mekânları ile bu gelenek devam ettirilmektedir.

Türkçede "ev" sözcügü̈, Latincede "domus" a yani ailenin barındığ 1 yapı terimine karşılık gelmektedir (Kuban 1995, 20). Türk evi; Osmanlı imparatorluğu sınırları içinde Rumeli ve Anadolu bölgelerinde oluşmuş, kendi özellikleriyle belirginleşmiş ve 500 yıl yaşamını devam ettirmiş ev tipidir. 15. ve 16. yüzyılda Anadolu'da kendine has bir karakterle ortaya çıkan ve en çok 17. ve 18. yüzyıllarda yaygın olarak görülen yapılar "Türk Evi" olarak tanımlanmıştır. Hatta bu dönemlerde İstanbul ve Edirne 'de bulunan yapılar taklit edilir hale gelmiştir. Osmanlı Devleti'nin çöküş dönemi 19. yüzyılda bile varlığını sürdürmeye devam etmiştir (Eldem 1954, 11).

Anadolu evleri ile ilgili çeşitli plan tipolojileri ortaya konulsa da yöresel özelliklerin, evler ile olan ilişkisi incelenmemiştir. Oysa ki, yapıların oluşumunu topoğrafya, iklim, bitki örtüsü, kültürel yapı etkilemekte ve şekillendirmektedir.

Araştırma konusunu Antalya İli Gazipaşa İlçesinde bulunan evler oluşturmaktadır. Halk tarafından üretilmiş özgün nitelikteki bu mimarlık eserlerinin hem biçimsel hem de fonksiyonel olarak korunup belgelenerek bu kültürel mirasın geleneklerinin gelecek kuşaklara aktarılması gerekmektedir. Daha önce Gazipaşa ilçesi ve köylerinde bu tür bir çalışma yapılmamış olması ilçe tarihi ve kültürü açısından önem arz etmektedir.

$\mathrm{Bu}$ çalışmada, Gazipaşa yöresi geleneksel ev mimarisi, hem plan yönünden hem de bu evlerin oluşumuna etki eden yöresel, kültürel, ekonomik, coğrafi ve inanç gibi çeşitli değişkenler düşünülerek ele alınmıştır. Yörede yer alan evlerin birçoğunun bu bölgede yaşamış insanların sosyal statüsü ve ekonomik durumlarına göre evlerin büyüklüklerinin de değiştiği izlenmektedir.

41 adet köy yerleşmesine (Bu bilgi Gazipaşa Belediyesi Numarataj Biriminden alınmıştır.) sahip ilçede yer adları, doğal yapı, kuruluş yerleri, dokuları, ekonomik faaliyetleri ve yaşayan köy halkına göre farklılık göstermektedir. Gazipaşa Antalya'nın en doğusunda yer alan ilçesi olduğu için, denize kıyısı olmasına rağmen, ilden gelecek olan yardım ve yatırımlardan payını alamamaktadır. Tarih boyunca yerleşim görmesine rağmen turizm açısından cazip hale gelememiş ve gerek merkezde gerekse kırsalda oturanlar iş bulabilmek için farklı il merkezlerine göç etmişlerdir. Bu nedenle ilçede bulunan geleneksel konutlar terkedilmiş ve kullanılmamaktadır. Yapılar kullanılmadığı için yıkılmakta ve hatta birçoğu yok olmaktadır. İncelenen yapılar arasında tescilli olan yapı sayısı ilçe merkezinde dört, Hasdere kırsalında ise sadece birdir. Yapıların tescilli olmaması, kalan yapıların da kullanılmaması sebebiyle yapıların birçoğu kullanılamaz hale gelmiştir. Hatta incelenebilecek nitelikteki konut sayısına bakıldığında yapıların tescilli olması sebebiyle günümüze kadar gelebildiği görülmüştür. Tescilli olmayan yapıların incelenmesi de tescillenebilir ihtimali ile yapı sahipleri tarafından hoş karşılanmamaktadır. Bu nedenlerle araştırma kapsamına tescilli yapılar ağırlıklı olmak üzere sahipleri tarafından izin verilen yapılar alınmıştır. Ayrıca özellikle iki adet yapıda nitelikli ve yörenin önemli kişilerinin olduğu söylenen yapıları bakımsızlıktan yıkılma tehlikesi olduğu için ölçüm için içerisine girilememiş ve plan rölöveleri çıkarılamamıştır.

İlçe genelinde barındırdığı turizm potansiyeli nedeniyle talep artmakta ve yapılaşma da paralel olarak her geçen gün artmaktadır. Özellikle ilçede maksimum kat yüksekliği 5 kat iken parsel büyüklüğüne göre kat sayısının artabileceğine dair alınan plan kararları ile yer sahipleri ve müteahhitler açısından daha cazip hale gelmeye başlamıştır. Bu nedenle ruhsatlı ve planlı yapılaşma yanında plansız yapılaşmalar da ilçede görülebilmektedir. Genellikle tek katlı ve bahçeli evlerde yaşayan, bahçesinde bir şey ekip hayvan besleyen insanlar bu yapılarını yıktırarak yerine yüksek katlı yapılar yaptırmakta ve buralara taşındıklarında ise mutsuz olmaktadırlar. Geçmişte taş ve ahşapla inşa edilen sürdürülebilir, komşusuna saygıll geleneksel yapılar yerlerini yüksek katlı yapılara bırakmaktadırlar. Bu da kişilerin yere olan aidiyet duygusunu kaybet- 
melerine sebep olmaktadır. İlçede oldukça az sayıda kalan geleneksel yapı örneklerinin belgelenmesi ve gelecek kuşaklara aktarılması, bunun için farkındalık yaratmak, yapıların olası işlevlendirilmelerine katkı sağlaması amaçlanmıştır.

\section{Gazipaşa}

Oldukça zengin kültürel ve doğal çeşitliliğe sahip Gazipaşa, Antalya'nın $180 \mathrm{~km}$ doğusunda, $10 \mathrm{~km}$ uzunluğa ve $7 \mathrm{~km}$ derinliğe sahip Gazipaşa Ovası ve Akdeniz Kıyısında bulunmaktadır (Fig. 1). Doğusunda Anamur, Kuzey doğusunda Ermenek, kuzeyinde Sarıveliler, batısında ise Alanya ile komşudur. Akdeniz sahilinin oluşturduğu güney sınırlarını kıyıya paralel ilerleyen yaklaşık $35 \mathrm{~km}$ içeriden Toros Dağları çevrelemektedir. Kuzeyindeki Toros Dağlarının batı kıyı sıradağları Akçal Dağları olarak adlandırılır (Antalya Valiliği İl Kültür ve Turizm ve Turizm Müdürlüğü 2010, 292).

Köklü bir geçmişe sahip olan Gazipaşa'nın tarihi antik çağlara kadar uzan-

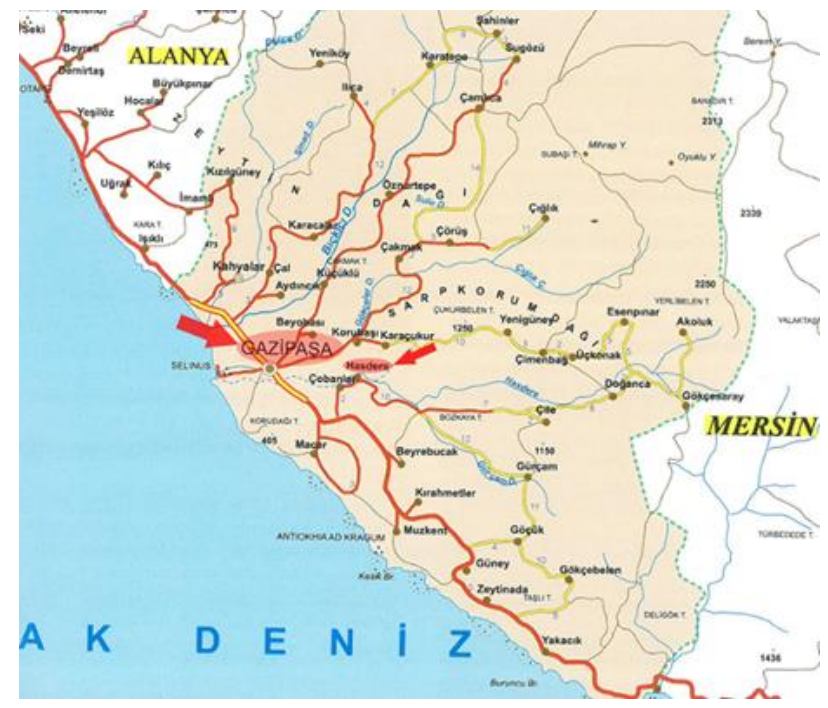

Fig. 1. Gazipaşa Haritası (Antalya Valiliği İl Kültür ve Turizm ve Turizm Müdürlüğü 2010, 292) maktadır. Yerleşim tarihi MÖ 2000'lere iner ve Luvilere kadar uzanır. Hitit yerleşimi ardından Hellenistik Dönem'de de yerleşim görmüştür. MÖ I yüzyılda Roma Dönemi'nde Kilikya Bölgesi içinde yer alır. Kilikya'nın dağlık Kilikya kısmında yer alan ilçe 4.yy.dan itibaren Bizans yerleşimi görmüş ve kent yeniden inşa edilmiştir. Selçuklu Sultanı 1.Alaaddin Keykubat'ın Alanya'yı ele geçirmesiyle Selçuklulara tabi olmuştur (Yıldız 2009, 22-38). Daha sonra Karamanoğulları Beyliği yönetimine girmiş ve sonrada Osmanlı topraklarına katılmıştır. Osmanlı hâkimiyetinden kısa bir süre önce İçel Sancağı'na bağlanmış ve bu sancak da Karaman Beylerbeyliği'ne bağlanmıştır (Gazel 2007, 700-701).

Gazipaşa, Akdeniz ikliminin yaşandığı coğrafyada yer almakta, yazlar sicak ve kurak kış ayları ise 1lık ve yağışlı geçmektedir. Kışın aldığı yağışların yoğunluğundan oluşan sel olaylarının fazlalığı nedeniyle ilçenin adı "Selinti" (Sel olaylarının fazla olduğu yer anlamına gelmektedir Akış 1997, 2) olarak anılmıştır (Akış 1997, 2). Anlam olarak aynı zamanda sel sular1nın bıraktığı malzeme anlamına da gelmektedir. $\mathrm{Bu}$ durum yaşanan doğa olaylarının yer adlarına yansıması için iyi bir örnektir.

\section{İlçe Merkezinde Bulunan Yapılar Gümrük Binası}

Pazarc1 Mahallesi 1361 Ada 2 Nolu parselde yer alan Gümrük Evi olarak bilinen ve konut amaçlı inşa edilmiş olan yapıda çevrede yapılan sözlü görüşmeler sonucu gümrük
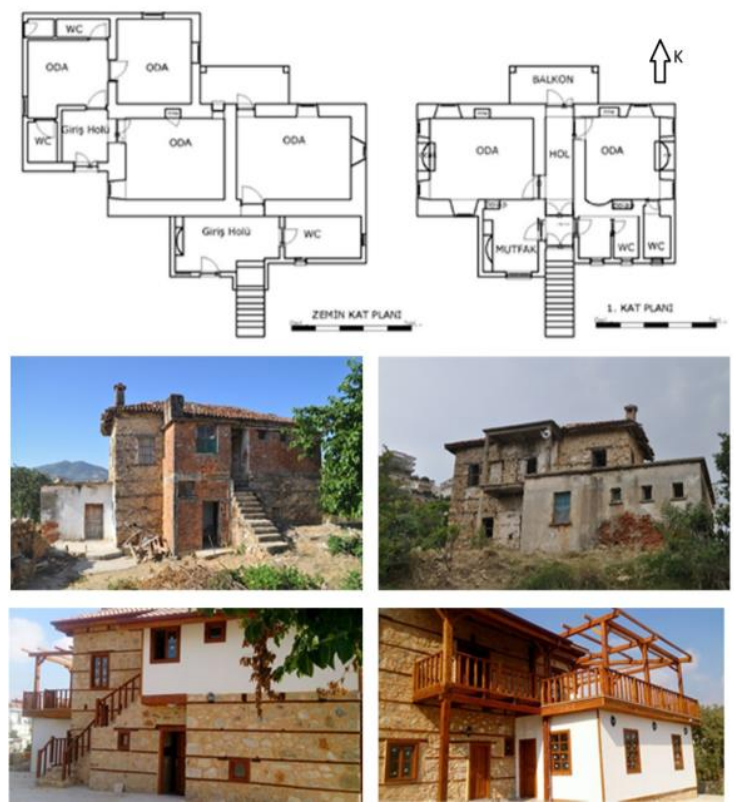

Fig. 2. Gazipaşa Pazarcı Mah.1361 Ada 2 Nolu Parsel Gümrük Binası Planlar 
memurunun yaşadığı bilgisine ulaşılmıştır. Asıl binanın yanına yapılan eklentinin de bir dönem gümrük ofisi olarak kullanıldığ 1 belirtilmiştir.

23.02.2010 tarihinde Antalya Kültür ve Tabiat Varlıklarını Koruma Kurulu Bölge Müdürlüğü tarafindan tescillenerek koruma altına alınmıştır.1930'lu yıllarda yapıldığı belirtilen yapı, biri tek diğeri ki katlı iki kütleden oluşmaktadır. Bir bahçe içerisine inşa edilen yapı ahşap hatıllı yığma taş duvar tekniği ile inşa edilmiştir.

Yapının iki katlı ana kütlesinin zemin katı gümrük binası lojmanı olarak kullanıldığ1 dönemlerde kalan kişinin hayvanını bağlaması için ahır olarak kullanılmıştır (Fig. 2). Daha sonra burası da konut olarak kullanılmıştır. Yapı oldukça fazla değişikliğe uğramış, betonarme ve tuğla eklentiler yapılmıştır. Yapının üst kat ara duvarları ahşap taşıyıcılı bağdadi tekniği ile yapılmıştır. Yapının kuzey cephesine yapılan tuğla eklenti sonraki kullanımlarda islak hacimlerin konut içerisine alınma ihtiyacı duyulmasıyla yapılmıştır. Yapının bir odasında güney duvarda yapılan bir niş ile kıble yönü belirlenmiştir. Geleneksel konutlarda dini inançların yansımasını göstermek için iyi bir örnek olmuştur. $\mathrm{Bu}$ değişiklik esnasında yapının üst kat giriş merdiveninin yeri değiştirilmiştir. Rölöve alımları sırasında yapının duvarlarında eski merdivenin izleri çıplak gözle görülmüş, restitüsyon ve restorasyon sırasında bu izlerin kullanılarak merdivenin orijinal yerine alınması proje müellifine teklif edilerek uygulanmıştır. Yapının çatı örtüsü kırma çatıdır ve üzeri Marsilya tipi kiremit ile kaplıdır.

23.02.2010 tarihinde Antalya Kültür ve Tabiat Varlıklarını Koruma Bölge Kurulu Müdürlüğü tarafından tescillenen yapı Gazipaşa Belediyesi tarafından restore (Yapının ayrıntılı incelenmesi ve taslak rölövelerinin çıkarılması 2008-2016 tarihleri arasında Antalya Gazipaşa Belediyesinde çalıştığım dönemde tarafımdan alınmıştır. Daha sonra idarenin restorasyon kararı verilmesi ile proje ihalesi yapılarak Gazipaşa Belediyesi kontrollüğünde Y. Mim. Emine Cimrin KOÇAK tarafından Rölöve, Restorasyon ve Restitüsyon projeleri hazırlanarak Koruma Bölge Kuruluna onaylattırılmıştır.) edilerek Restoran olarak kullanılmaktadır.

\section{Hacı Peder Evi}

Pazarc1 mahallesi 33 Ada 14 Parselde bulunan yapı Hac1 Peder evi olarak bilinmektedir. 02.06.2009 tarihinde Antalya Kültür ve Tabiat Varlıklarını Koruma Kurulu Bölge Müdürlüğü tarafindan tescillenerek koruma altına alınmıştır. Geleneksel yapı araziye yaklaşık Kuzey- Güney doğrultusunda yerleştirilmiş̧ir. Yapı İki katlı ve ahşap hatıllı yığma taş duvar tekniğinde yapılmış olup, kuzey cephede ikinci katta bağdadi bir cumba vardır. Cumba zeminde ahşap direklerle taşınmaktadır ve zemin katta ahşap direklerin arasında bulunan pencerenin ise orijinalinde kapı olarak yapılmış sonradan pencereye dönüştürülmüş olduğu düşünülmektedir ve restorasyon sirasinda da bu durum dikkate alınıştır. Yap1 zeminde 9.60x10.60 m yaklaşık kare formludur (Fig. 3).

Üst kata giriş güney cepheden önceden ahşap olduğu muhtemel olan fakat daha sonra betonarme olarak değiştirilen merdiven ve önünde bir balkondan sağlanmaktadır. Restorasyon sırasında bu betonarme eklenti kaldırılarak taş basamaklı ahşap bir giriş balkonu inşa edilmiştir. Alt kata ise bu balkonun altından ahşap bir kapıdan girilmektedir. Tipik Türk

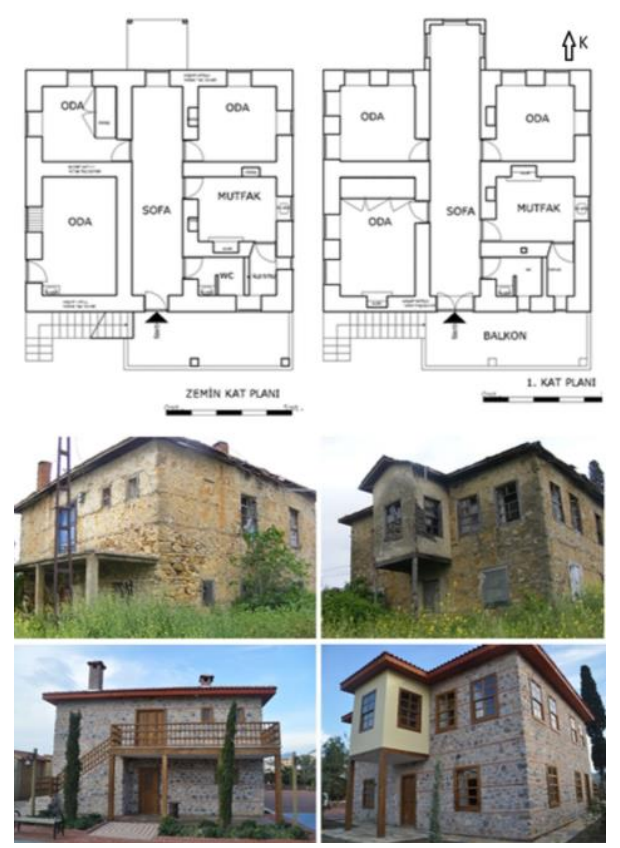

Fig. 3. Gazipaşa Pazarcı Mah.33 Ada 14 Nolu Parsel Hacı Peder Evi Planlar ve restorasyon öncesi ve sonras1 görünüşler (Mim. Şükran Gülücü URAL tarafindan çıkarılan taslak rölöve altlık olarak kullanılarak tarafımdan yeniden çizilmiştir.) 
Evi planına ve yerleşimine sahip olan konutun her iki katında günlük yaşamın geçtiği düşünülen odalarında yüklük bulunmaktadır. Her iki katta da mutfak olduğu düşünülen mekânda pencere içlerine lavabo yerleştirilmiştir. Dış ve iç cephelerinde süsleme elemanı olmayan yapıda her iki katta bulunan ocaklara bakıldığında, iki katın da ayrı ayrı, müstakil konutlar olarak kullanılmış olduğu düşünülmektedir. Zemin Katta, güneybatıda dışarıya açılan, zemin kat ile bağlantısı bulunmayan bir oda bulunmaktadır. Bu oda ortak kullanıma veya üst kattakilerin kullanımına ayrılmış bir mekân olmalıdır.

Yapı Gazipaşa Belediyesi mülkiyetinde olup restore edilerek üst katı nikâh salonu alt katı ise kafeterya olarak kullanılmaktadır. Restorasyon (Yapının ayrıntılı incelenmesi 2008-2016 tarihleri arasında Antalya Gazipaşa Belediyesinde çalıştığım dönemde tarafımdan yapılmıştır. Daha sonra idarenin restorasyon kararı verilmesi ile proje Gazipaşa belediyesi kontrollüğünde Mim. Şükran Gülücü URAL tarafindan Rölöve, Restorasyon ve Restitüsyon projeleri hazırlanarak Koruma Bölge Kuruluna onaylattırılmıştır.) kararları alınırken konutta bulunan izler düşünülmüş ve orijinal kullanımına yakın bir proje hazırlattırılmıştır.

\section{Mevlüt Akça Evi}

Yap1 Yeni mahalle 362 Ada 8 Parselde bulunmaktadır. 23.02.2010 tarihinde Antalya Kültür ve Tabiat Varlıklarını Koruma Kurulu Bölge Müdürlügü tarafindan tescillenerek koruma altına alınmıştır. Geleneksel yapı araziye yaklaşık Kuzey-Güney doğrultusunda yerleştirilmiştir (Fig. 4). Yapı iki katlı ve ahşap hatıllı yığma taş duvar tekniğinde yapılmış olup, güney cephede ikinci katta sofanın ucunda bağdadi bir cumba vardır. Bağdadi cumba zeminde ahşap direklerle taşınmaktadır. Zemin katın girişi bu direklerin arasındandır. Yapı zeminde $6.00 \times 9.30 \mathrm{~m}$ 'dir. Her iki kat konut olarak planlanmıştır. Üst kata çıkış kuzey cepheden bir merdivenle sağlanmaktadır. Daha önceden ahşap olan merdiven daha sonra betonarme olarak değiştirilmiş olmalıdır. Yapının zemin katına ve birinci katına betonarme tuğla eklentiler yapılarak islak hacimler eklenmiştir. Yapının çatısı ahşap oturtmalı kırma çatı olup, Marsilya tipi kiremit ile kaplıdır. Yapı günümüzde kullanılmamaktadır.

Konutun her alanı oldukça iyi değerlendirilmiştir. Niş şeklinde yapılan dolapların kapakları açılarak depo gibi küçük mekana açılmaktadır. Yapıda konut olarak kullanılan alt katında odanın bir tanesi zeminden yükseltilerek yüklük veya yatma yeri olarak planlanmıştır.

\section{Çevlik Mevki Ali Tepe Evi}

Bakılar Mah. Çevlik Mevki 731 Ada 7 parselde bulunan yapı ahşap hatıllı yığma taş duvar tekniği ile yapılmıştır. Ali TEPE'ye ait olan evin yapım tarihi

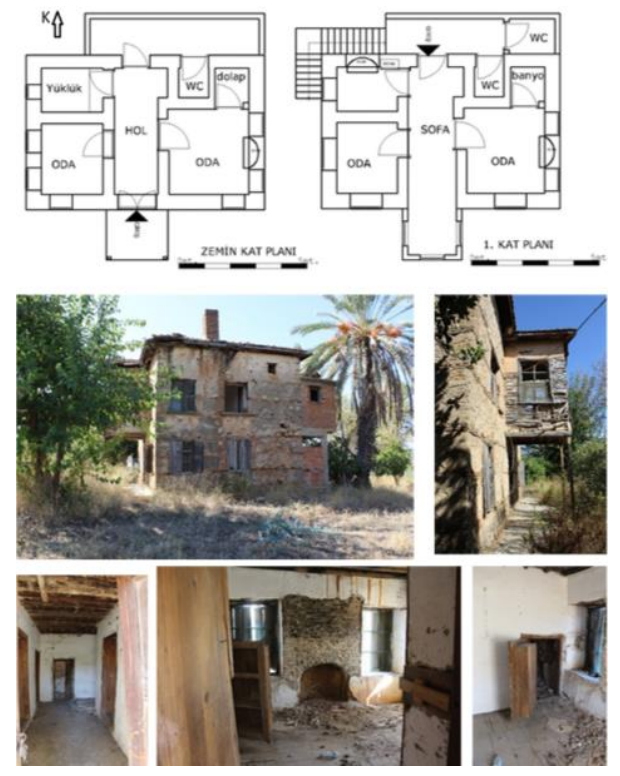

Fig. 4. Gazipaşa Yeni Mah. 362 Ada 8 Nolu Parsel Mevlüt AKÇA Evi Plan ve görünüşler

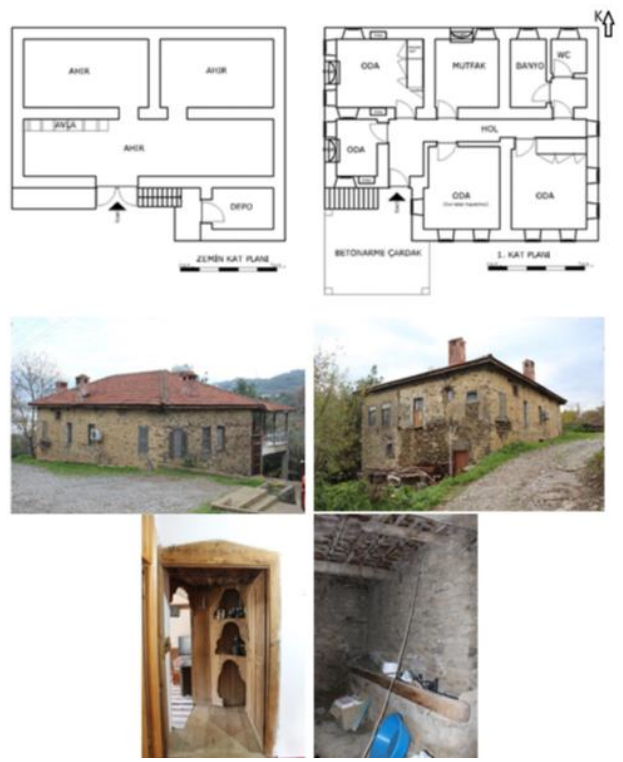

Fig. 5. Gazipaşa Bakılar Mah. 731 Ada 7 Nolu Parsel Ali TEPE Evi Plan 
1926 olarak yapı sahipleri (Yapı sahibinin torunları olan ve evde hala yaşamakta olan Ali Tarık TEPE ve Meral TEPE'den bilgi alınmıştır.) tarafından belirtilmiş, ayrıca evin Alanya'dan gelen Kıbrıslı ustalar tarafından yapıldığını ve derzlerde kullanılan kiremit kırıklarının Kıbrıs'tan getirildiği bilgisini vermişlerdir. Yap1 1997 yılında esaslı bir tadilat geçirmiştir. 23.02.2010 tarihinde Antalya Kültür ve Tabiat Varlıklarını Koruma Kurulu Bölge Müdürlüğü tarafından tescillenerek koruma altına alınmıştır. Yapının orijinal planı oldukça değişim göstermektedir (Fig. 5). Yapı sahiplerinin aktardığı bilgiye göre yapı ilk başta açık sofalı ve bağdadi cumbalı bir yapı iken, zamanla ihtiyaçlar doğrultusunda açık sofa kapatılmış, önüne betonarme bir çardak yapılmış, açık sofanın bir kısmı odaya dönüştürülmüş, bağdadi cumba kaldırılarak bu kısıma banyo ve wc eklenmiştir. Yapıda eskiden bir çağnişir olduğu da yapı sahipleri tarafından aktarılmıştır. Yapının ilk kullanımından bu yana geçirdiği değişimler duvarlarda izlenebilmektedir. Yapının derzlerinde kullanılan kiremit kırıkları Alanya'ya özgü bir uygulama olup, Gazipaşa evlerinde pek görülen bir durum değildir. Bu da yapıyı Alanya'dan gelen ustaların yapmasının etkisi büyüktür. Yapı alt katı ahır olmak üzere iki katlıdır. Ahır kapısının yüksekliği 243 cm'dir. Oldukça yüksek inşa edilen kapı, evde deve olduğunun göstergesidir. Alt katında üç odalı ahır bulunmaktadır. İlk giriș sağ tarafta ahır içerisinde depo amaçlı bir asma kat bulunmaktadır. Üç gözlü ahır dışında yapıda ayrı girişli bir depo bulunmaktadır. Bu deponun üst katı yani konut ile depo arasında eğimden kaynaklı oluşan yükseklikte çalışanların kalması için tek göz bir oda inşa edilmiştir. Bu plan özelliği daha önce Gazipaşa evlerinde karşılaşmadığımız bir durumdur. Yapının plan şeması günümüze orijinal olarak gelememiş olsa da sahipleri tarafindan hala kullanılmaktadır.

Her odasında ocaklık bulunan yapının günümüze kadar gelebilen ocak sayısı ikidir. Odalardan bir tanesinde dolap içerisinde yıkanma yeri bulunmaktadır. Aynı dolabın devamında "lambalık" adı verilen köşeli, bir raf bulunmaktadır. Şu anki kullanımda mutfak ve banyo olarak kullanılan kısım daha önceden halk arasında "içiçeri" adı verilen iki odanın dolapla birbirinden ayrıldığı ve bir kapı ile birbirine geçilebildiği odalar olduğu yap1 sahipleri tarafından aktarılmıştır. Bu kısım Alanya evlerinde görülen yazlık ve kışlık mekânlardan "kışlık" mekân olduğu düşünülmektedir.

\section{Kâhyalar Mahallesinde Bulunan Ev}

Gazipaşa İlçesi Kâhyalar Mahallesinde bulunan yapı Kâhyalara adını veren kişinin oturduğu ev olarak bilinmektedir. Yapı büyük ölçüde yıkıldığı için ölçü alınamamıştır. Fotoğraflanarak belgelenmiştir (Fig. 6). Yapı duvarlarında kullanılan devşirme taşlar ve süslemeli pencere, ocaklık ve rafları dikkat çekicidir. Yap1 ahşap hatıllı yığma taş duvar tekniği ile inşa edilmiş olup günümüze kadar sadece bir odas1 korunagelmiştir. Yap1 eğimli bir arazide ve manzaraya hâkim bir şekilde yerleştirilmiştir. Yapı duvarlarında yakında bulunan bir antik yerleşimden getirildiği düşünülen devşirme taşlar kullanılmıştır. Bunlardan nar ve çiçeği kabartması olan bir köşe taşı yalnızca ilçede yetiştirilen ve festivali de yapılan çekirdeksiz nar ile ilgili olabileceği düşünüldüğünden ilgi çekicidir. Tescilsiz olan yapının en kısa zamanda tescillenerek koruma altına

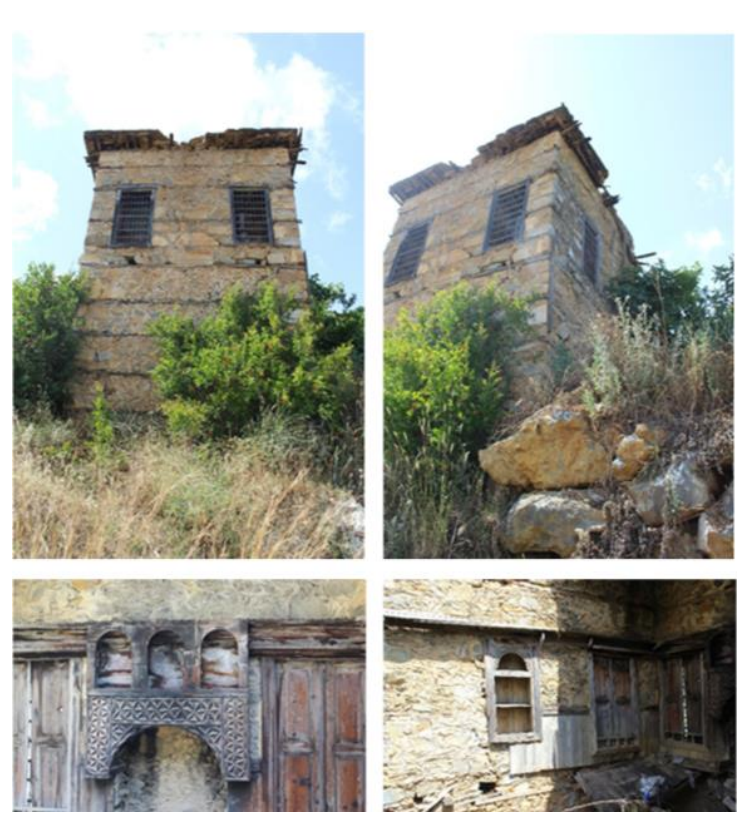

Fig. 6. Gazipaşa Kâhyalar Mah. Kâhya Evi Görünüşler 
alınmas1 gerekmektedir.

\section{Hasdere Mahallesi}

Hasdere köyü İlçe Merkezine 8 km uzaklıkta bulunan küçük bir yerleşmedir (Yıldız 2009, 450). Ova tabanına kurulmuş bir yerleşim olan Hasdere, ilçenin en eski yerleşimlerinden biri olması bakımından ilçe tarihi açısından önemlidir. Halkın geçim kaynağı tarım olduğu için evler plansız bir şekilde geniş alana yayılmışlardır. Ayrıca köye mevsimsel tarım işçilerinin belli dönemlerde göçleri de görülmektedir. $\mathrm{Bu}$ durum bahçelerde işçi evleri yapma ihtiyac1 oluşturmuştur. Güneyi Aydoğdu Beleni, kuzeyi ise Çerçi Beleni ile çevrilmiş olan köy bu iki tepe arasında eğim yönünde ve dereye doğru yerleşmiştir. Köy kendi içerisinde KöpenliÇatalharmanı, Pınaralanı, Sabık ve Merkez olmak üzere (Bilgi, Gazipaşa Belediyesi numarataj biriminden bilgi alınmıştır) dört mevkiden oluşmaktadır. Köy nüfusu 2013 yılında 647 iken 2017 yılında 613 kişi olmuş ve yıldan yıla azalan bir ivme göstermiştir (TÜİK Nüfus Sayım İstatistikleri, 2017).

\section{Medrese Hocası Halil A ğa Evi}

Erzurum Horasan'dan 18. yüzyılın son çeyreğinde göç ederek gelen Halil Ağa, mezarlığın karşısında bir medrese kurmuş ve yukarı kısma bir ev yaparak buraya yerleşmiştir (Medrese hocasının 2. Kuşak torunu Gürsel Öğüt'ten 15.02.2018 tarihinde Hasdere'de bilgi alınmıştır.). Köye hâkim bir noktaya girişi kuzeye bakacak şekilde konumlandırılan iki katlı eve bir patikadan çıkılarak ulaşılmaktadır. Akdeniz ikliminin önemli bir bileşeni olan güneşin olumsuz etkilerinden korunmak için güney ve güneybatı yönünde, yörede oldukça fazla görülen incir ve keçiboynuzu ağaçları ekilmiştir. Bahçe duvarı olmayan, doğayla iç içe bir yerleşim sergileyen konut, tamamen sürdürülebilir yapı malzemeleri ile inşa edilmiştir ve doğaya zararlı bir yapı malzemesi bulunmamaktadır.

Dıştan 9,72x8,14 m ölçülerindeki yapının, kuzey cephede üst kata çıkan ahşap merdivenlerin altında yörede "borda" adı verilen $1.78 \mathrm{~m}$ genişliğinde çift kanatlı bir kapı ile yapının alt katına girilmektedir. Yapının zemin katı ahır olarak kullanılmıştır (Fig. 7). Bu kata giriş kapısı normal ahşap kapılardan daha yüksektir. Bu da o dönemde hemen hemen her evde bulunan ve yaylaya göçerken yük taşımak için beslenen develerin olmasından kaynaklanmaktadır. Burada duvar boyunca ve duvardan yaklaşık $0.50 \mathrm{~m}$, yerden $0.80 \mathrm{~m}$ yüksekliğinde "avla" ad1 verilen yemlikler bulunmaktadır. Üç ayrı mekândan oluşan bu katta pencereler küçük 1şıklıklar şeklinde yapılmıştır. Yine kuzey cepheden ilk üç basamağ 1 taş, 12 basamağ1 ahşap olmak üzere toplam 15 basamakla cepheye dişarıdan bitişik merdivenle yapının üst katına geçilmektedir. Günümüzde yıkık olan sofanın ön kısmı ahşap malzemeden yapılmıştır. Yap1 açık sofalı iken daha sonra kapatılmış olabilir. Üst katta sofaya açılan iki adet oda bulunmaktadır. Bu odaların büyük olanında iki, küçük olanında ise bir adet ocaklık bulunmaktadır. Yapının duvarlarında dolap nişleri yanında güney duvarında kıble

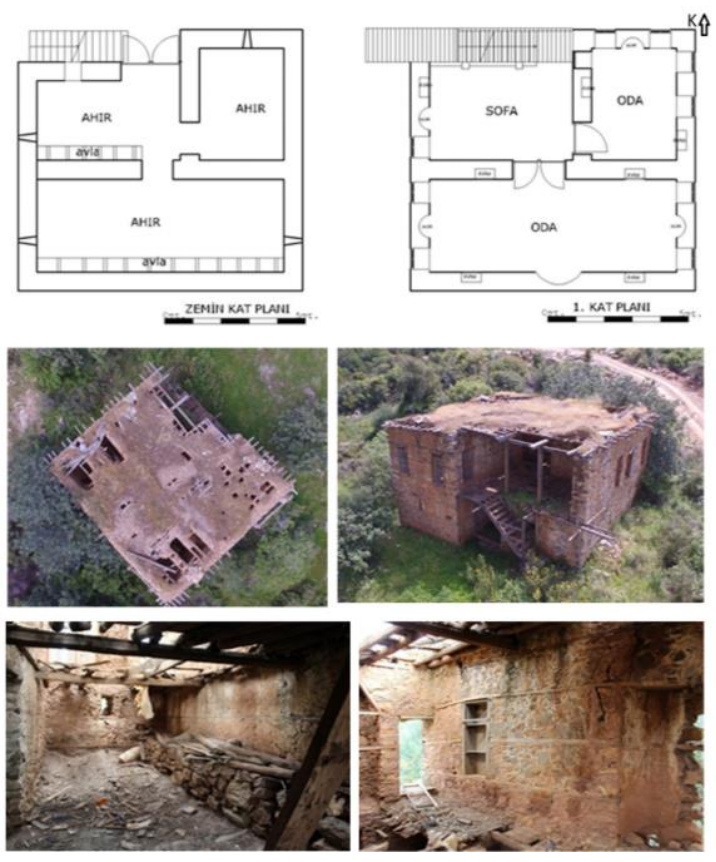

Fig. 7. Gazipaşa Hasdere Mah. Mederese Hocası Evi Plan ve Görünüşler 
nişi olması dini inançların geleneksel yapıya yansıması bakımından önemlidir.

Yapının çatısı sıkıştırılmış toprak dam şeklindedir. Bu toprak yalıtım sağlamak amacıyla mevsim geçişlerinde ve yağmurlar başlamadan önde "yuvak taşı" adı verilen silindir şeklinde bir taşla yuvarlanarak sıkıştırılmaktadır.

\section{Mustafa Hatipoğlu Evi}

Köy halkı ile yapılan görüşmelerde Mustafa Hatipoğlu'na ait olduğu söylenen konut tek katlıdır. Yapı; arazi eğiminden dolayı ve zemini nemden koruma amaçlı olarak yerden yaklaşık $1.42 \mathrm{~m}$ yüksek yapılmıştır. Bu yükseklikten dolayı alt kısımda oluşan küçük bir mekân odunluk ve/veya kümes olarak kullanılmış olmalıdır. Dıştan 6,65x10,20 m ölçülerindeki yapı üç odadan oluşmaktadır ve yapıda yüklük gusülhane olarak kullanılan bir de bölme bulunmaktadır (Fig. 8). Geleneksel plan tipi bakımından iç sofalı olarak tanımlayabileceğimiz konutta mahremiyet nedeniyle gusülhanenin olduğu duvar sağır birakılmıştır. Yapıda kuru duvar tekniği ile yapılmış bahçe duvarı bulunmaktadır. Teraslamalar yapılarak

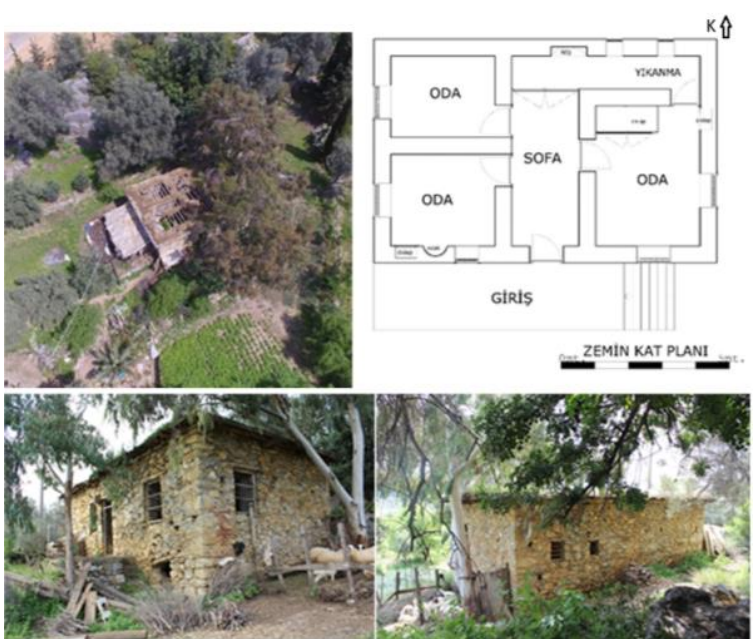

Fig. 8. Gazipaşa Hasdere Mah. Mustafa Hatipoğlu Evi Üst Görünüș ve Plan düzlükler elde edilmiş ve bahçe bu şekilde oluşturulmuştur. Yapının girişi güneye konumlandırılmış, kuzey ise daha çok sağır cephe olarak düzenlenmiştir. Çatısı toprak damdır, geleneksel mimaride bilinen "Yuvak Taşı" ile her yıl dam toprağının sıkıştırılması gerçekleştirilmektedir. Yapının güney cephesinde bulunan okaliptüs ağacı ile güneşin etkilerinden korunmak istendiği sonucu çıkarılabilir.

\section{Kâtip Mustafa Efendi Evi}

Geleneksel tanımlarda iç sofalı ev olarak adlandırılabilecek yapı üç odalı olarak inşa edilmiş, daha sonra yapıya ayrı girişli misafir odası eklenmiştir. Zaman zaman ihtiyaca göre yapıda bazı kapı ve pencereler kapatılarak değişiklikler yapılmıştır. Mahremiyet nedeniyle yüklük/ gusülhanenin bulunduğu duvar sağır bırakılmıştır. Yap1 iki katlıdır ve alt katı ahır olarak kullanılmıştır (Fig. 9). Geniş "borda" denilen ahır kapısından girildikten sonra alt kat odalar1nın duvarlarında "avla" denilen hayvan yemlikleri bulunmaktadır. Yapının ana girişi güneye yönlendirilmiş ve sağır duvarlar kuzeye bakacak şekilde konumlandırılmıştır. Yapının üst katının kuzeyinde de bir giriş kapısı olduğu ve daha sonra kapatıldı $\breve{g}_{1}$ tespit edilmiştir. Misafirhane olarak kullanılan bitişik yapının girişi batı yönünde konumlanmıştır. Yalnızca komşu parselle ortak kullanılan kuru duvar tekniği ile örülü taş bir bahçe duvarı bulun-

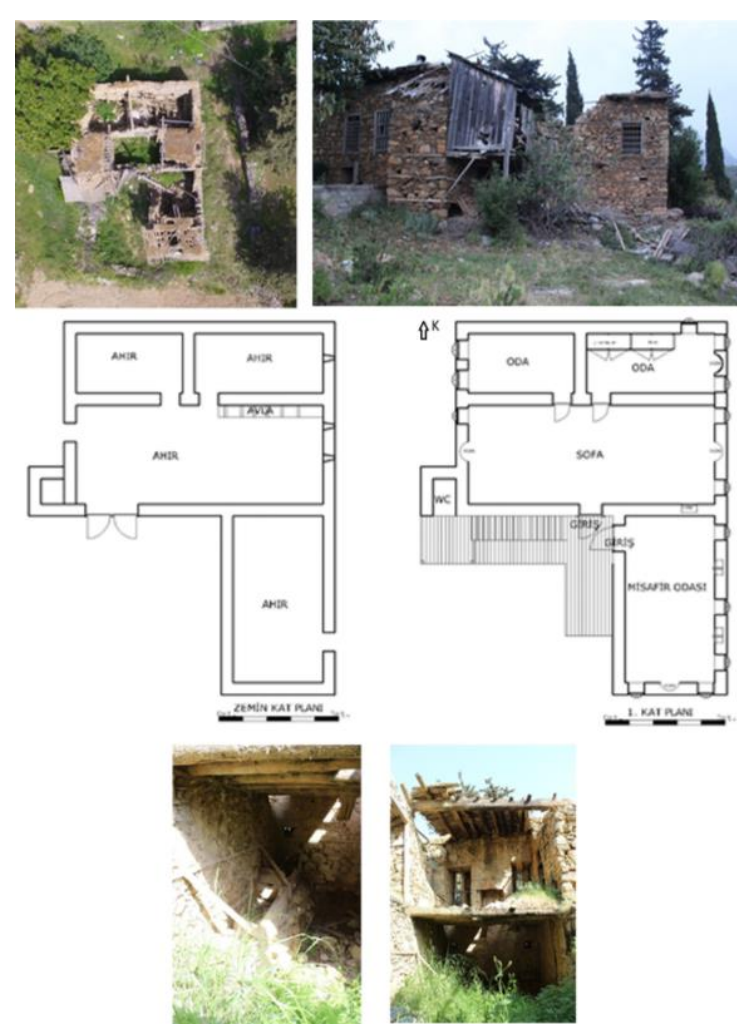

Fig. 9. Gazipaşa Hasdere Mah. Kâtip Mustafa Evi Plan ve Görünüşler 
maktadır. Yapı doğayla içiçe bir görünüme sahiptir. Akdeniz ikliminin önemli bir bileşeni olan güneşin olumsuz etkilerinden korunmak için yapı etrafında yörede oldukça fazla görülen incir ve keçiboynuzu ağaçları bulunmaktadır.

\section{Fevzi Aktaş Evi}

Geleneksel tanımlarda iç sofalı ev olarak adlandırılabilecek yapı ahşap hatıllı yığma taş duvar tekniği ile inşa edilmiştir. Yapı iki katlıdır ve alt katı ahır olarak kullanılmıştır (Fig. 10). İki hacimden oluşan, geniş "borda" denilen ahır kapısından girildikten sonra alt kat odalarının duvarlarında "avla" denilen hayvan yemlikleri bulunmaktadır. Ahırın duvarlarında küçük mazgal şeklinde havalandırma pencereleri bulunmaktadır. Üst katta betonarme bir merdivenle kuzey cepheden çıkılmaktadır. Bu cephede bir çardak inşa edilmiştir. Çift kanatlı ahşap bir kapı ile girilen yapının sofasına odalar açılmaktadır. İlk olarak iki odalı olarak inşa edilmiş, daha sonra ihtiyaçlar doğrultusunda eklenti yapılarak üçüncü bir oda ve ıslak hacim eklentisi yapıldığı yapıdaki izlerden tespit edilmiştir. Yapıda iki odayı birbirinden her iki odaya da açılan bir dolap ayırmaktadır. Odalarda bulunan niş şeklindeki dolapları ise süslemelidir. Sofa ve iki odada ocaklık bulunmaktadır. Yapı son zamanlara kadar kullanıldığı için betonarme ve tuğladan birçok eklenti yapılmıştır. Tescilsiz olan yapı, günümüzde kullanılmamaktadır.
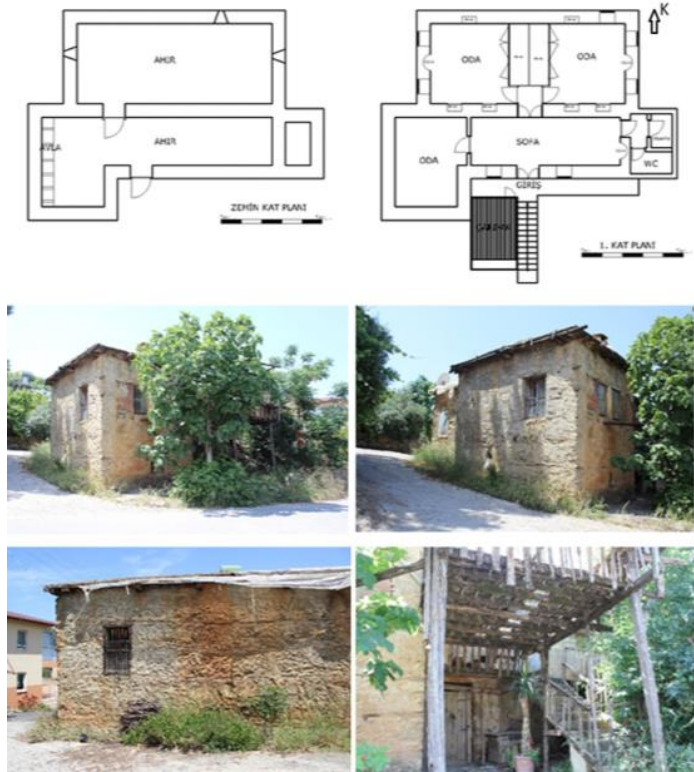

Fig. 10. Gazipaşa Hasdere Mah. Fevzi AKTAŞ Evi Planlar

\section{Derebeyi Evi}

Yap1 Hasdere Derebeyinin Evi olarak bilinmektedir. Hasdere Mah. 619 parselde Hacı Musa Çayı kenarında vadiye hâkim bir konumda bulunmaktadır. 2010 yılında Antalya Kültür ve Tabiat Varlıklarını Koruma Bölge Kurulu tarafindan tescillenen yapı oldukça yıkık durumda olduğu için planı çıkarılamamış ve ölçü alınamamıștır. Detaylı fotoğraflandırılarak belgelenmiştir (Fig. 11). Yapıda dışarıdan taş duvar izleri takip edildiğinde yap1 topluluğu şeklinde bir plana sahip olduğu müştemilatları ile birlikte
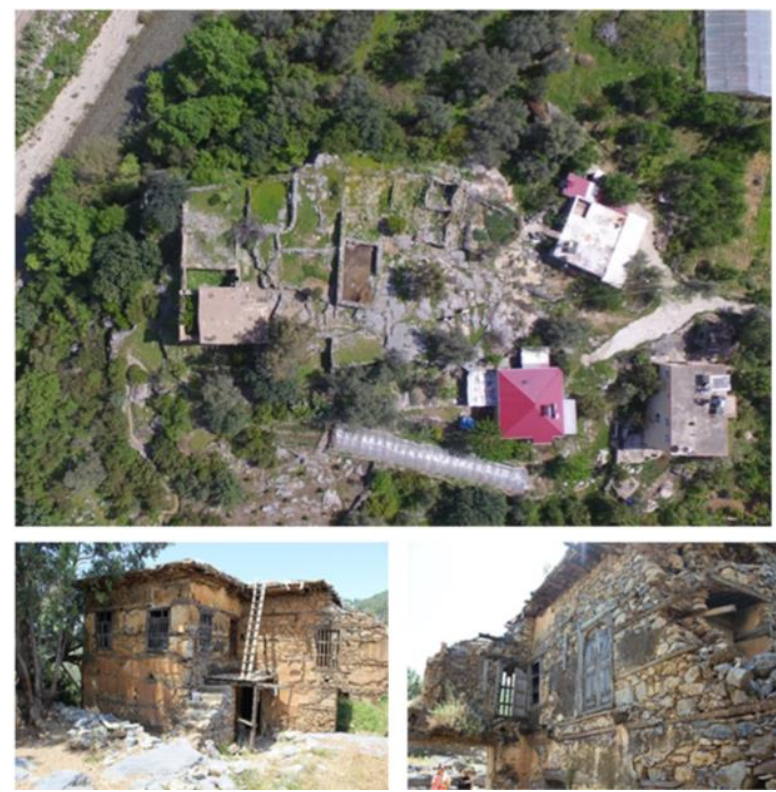

Fig. 11. Gazipaşa Hasdere Mah. Derebeyinin Evi Üst Görünüş

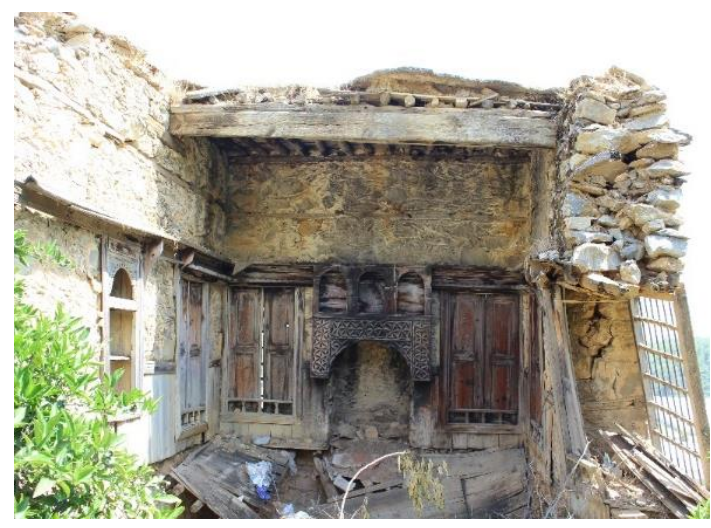

Fig. 12. Ahşap ve Demir Uygulama Örnekleri 
oldukça büyük bir yapı olduğu tespit edilmiştir. Yapı için daha detaylı ve profesyonel ölçüm cihazları ile ölçüm yapılarak belgelenmesi gerekmektedir.

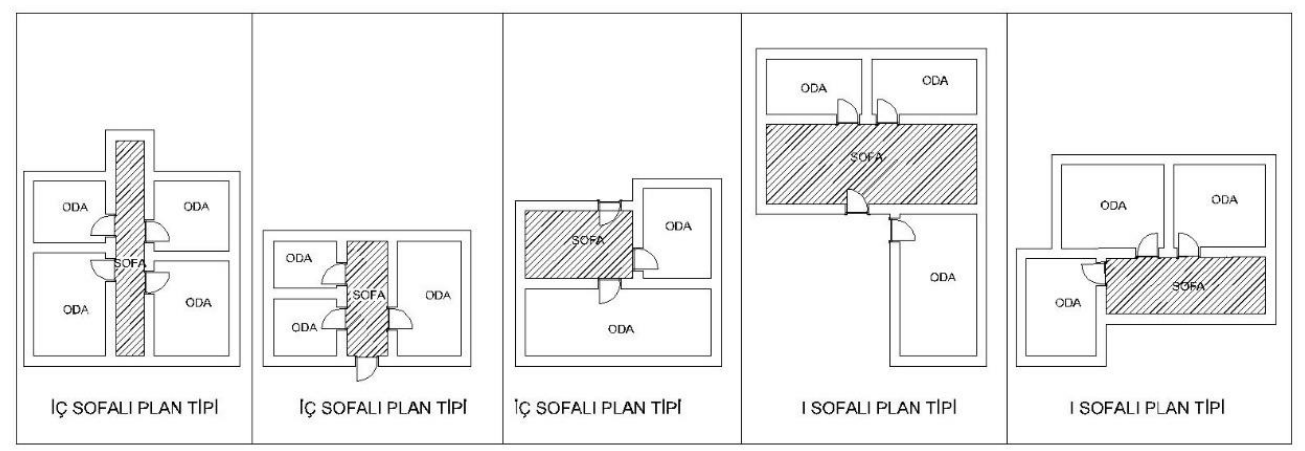

Fig. 13. Gazipaşa Evleri Plan Tipleri

\section{Değerlendirme ve Sonuç}

Gazipaşa Evlerinin mimari ana malzemesini taş ve ahşap oluşturmaktadır. Taş, ahşap hatıllarla birlikte temel ve ana gövdeyi oluşturmaktadır. Yani Gazipaşa evlerinin beden duvarları ahşap hatıllı yığma taş duvarlardan oluşmaktadır. Ahşap olarak genellikle yörede bulunan ardıç, sedir, katran ve çam ağacı tercih edilmiştir. Ahşap, hatıllar, puştivanlar dışında döşeme, tavan, pencere ve kapı doğramaları, dolaplar ve ocak üstü süslemelerinde kullanılmıştır. Ahşap karkas iç duvar bölmelerinde ve iç sofadan yapılan dışarıya yapılan çıkmalarda kullanılmıştır. $\mathrm{Bu}$ da taşıyıcı ahşap dikmelerin üzerine bağdadi çıtaların çakılarak sıvanmasıyla yapılmıştır. Demir, pencere korkuluklarında, kapı pencere kepenklerinin menteşelerinde kullanılmıştır (Fig. 12).

Evlerin üst örtüleri sıkıştırılmış toprak dam veya kırma çatı ile kaplıdır. Kırma çatılarda Marsilya tipi veya alaturka tipi kiremit kullanılmıştır. Tüm geleneksel yapılarda olduğu gibi planı şemasını iklim, topoğrafya, kültür, ekonomik yapı şekillendirmektedir. Gazipaşa evleri genellikle iki katlı olup alt katları ahır veya depo olarak, üst katlar ise asıl yaşam alanı olarak kullanılmıştır. Bazı konutların alt katları konut olarak planlanmıştır. Sedat Hakkı Eldem planı etkileyen unsurları odalar, sofalar ve merdivenler olarak belirtmiştir (Eldem 1954, 14). Odaların sayısı, yönü, kullanım amacı, odanın şekli, pencere ve kapıların bulunacağı cephe plan bakımından önemlidir. Odaların konumlanmasına göre şekil alan sofalar da Türk Evi plan Tipi sınıflandırmasında önemli unsurdur. Üst kata ulaşım merdivenlerin konumu sofa içerisinde veya dışarısında planlanmıştır. Eldem (1954) Türk evini sofalarına göre plan tiplerine ayırmıştır. Buna göre Gazipaşa'da yapılan incelemede, iç sofalı ve I sofalı plan tipi daha çok görülmektedir (Fig. 13). Merkezde bulunan bir yapıda açık sofalı plan tipi olduğu tespit edilmiştir fakat evde yapılan esaslı tadilatlar orijinal planı bozmuş olduğundan tam olarak tespit edilememiştir. Evlerin kuzey cepheleri genellikle sağır bırakılmıştır. Giriş kapıları ise iki katlı yapılarda eğer çıkma varsa alt katın girişi çıkmanın altından üst katın girişi ise farklı bir cepheden verilmiştir. Evlerde odaların içerisinde bulunan dolapların bir kısmı yıkanma yeri olarak düzenlenmiştir. Tuvalet ise çoğu yapıda dışarıda planlanmış, daha sonra ihtiyaca göre yapıya eklenmiştir. Her evin mutfağında ve bir odasında ocaklık bulunmaktadır. Bazı örneklerde tüm odalarda ocaklık bulunmaktadır.

Geleneksel yapılar geçmiş, şimdi ve gelecek arasında bir köprü görevi görüp, bağlarımızı kuvvetlendiren, içinde yaşamış veya hala yaşamakta olan kişilerin kültür, ekonomik yapı, sosyal yaşantıları hakkında fikir sahibi olmamızı sağlayan değerlerdir. Her ne kadar bir takım kanunlarla korunmaya ve restore edilerek gelecek kuşaklara aktarılmaya çalışılsa da, yaşam şekillerinin değişmesi, teknolojinin ilerlemesi, insanların evlerden beklentilerinin değişmesiyle ilgisiz ve bakımsız kalan geleneksel yapılar, iklim etkileri, genellikle ahşap olan yapı malzemelerinin dayanıksızlığ gibi etkenlerle yok olmaktadırlar. Bu yok oluştan Gazipaşa Evleri de payını 
almıştır. İlçe genelinde oldukça az sayıda geleneksel konut korunabilmiştir. İlçe merkezi ile kırsal yerleşim olan Hasdere mahallesinde bulunan konutlar arasında yaşayış biçimleri bakımından farklılık olmasından kaynaklı olarak konut planlarında ve büyüklüklerinde farklılıklar bulunmaktadır. Merkezde bulunan konutlar genellikle iki katlı ve her iki katı da ayrı ayrı iki bağımsız bölüm olmak üzere konut olarak inşa edilmiştir. Fakat Hasdere kırsalında konutlar tek veya iki katlıdır ve konutların alt katları genellikle ahır veya depo olarak kullanılmaktadır. Ayrıca kırsalda bulunan konutların çatısı sıkıştırılmış topraktan düz dam şeklindeyken, merkezde bulunan yapıların çatıları ahşap oturtmalı kırma çatı ve üzeri kiremit kaplıdır. Bu kullanıcıların ekonomik durumları ile ilgili olmalıdır. Yapılarda cephe ve süsleme bakımından kırsal ve merkezde sadelik hâkimdir. Yalnız merkezdeki konutların bir kaçında iç sofadan bağdadi tekniği ile yapılmış cumba çıkıntısı varken kırsalda konutlar cumbasızdır. Kırsalda bulunan yapıların tamamı ahşap hatıllı yığma taş duvar iken, merkezde bulunan yapılarda üst kat iç mekân bölme duvarlarda ahşap taşıyıcılı bağdadi sıvalı duvarlar kullanılmıştır. Merkezde ve kırsalda incelenen birer adet konutta tespit edilen güney duvarda kıble nişi dini inançların ve yaşayışın geleneksel yapılara nasıl yansıdığının bir göstergesidir. $\mathrm{Bu}$ farklılıklar dışında yapılarda kullanılan malzeme, teknik, süsleme kırsal ve merkez ayrımı olmaksızın benzerdir. Evler yakın çevrede Alanya ve Antalya'da bulunan geleneksel konutlarla kıyaslandığında daha az işçilikli ve yerleşim bakımından daha dağınık bir yerleşme olduğu görülmektedir. $\mathrm{Bu}$ farklılıklarda geleneksel konutlara, kültür, yaşayış şekli, ekonomi, inançlar gibi birçok unsurun etkili olduğu sonucunu çıkarmaktadır. Birçoğu 19. yüzyıla tarihlenen Gazipaşa'da bulunan geleneksel konutlar sahipleri tarafından işlevsel olmadığı ve günümüz ihtiyaçlarına cevap vermediği için terkedilmiştir. Merkezde bulunan yapılardan iki tanesi Gazipaşa Belediyesi tarafindan restore edilerek işlevlendirilmiştir. $\mathrm{Bu}$ işlevlendirmelerin yapılar üzerindeki etkisi farklı bir tartışma kapsamına değerlendirilebilir. Yapılar kullanılmadıklarında daha çabuk yıpranmakta ve yok olmaktadırlar. Son yıllarda tescilli yapılar için parasal yardımlar artmıştır. Bu yardımların kapsamı ve kullanılabilirliği konusunda halkın biraz daha bilinçlendirilmesi gerekmektedir. Yapıların korunması ile ilgili bir diğer sorun da yapı restore edileceği sırada nitelikli taş veya ahşap ustasının oldukça zor bulunmasıdır. Düzgün yapılamayan restorasyonlar yapıların gelecek kuşaklara aktarımında yanlış bilgiler barındırabilmektedir. Özellikle Hasdere kırsalında sayıca fazla olan ve kullanıcıları tarafından özgün malzeme ile tamamen zıt malzemelerle yapılan eklentiler, onarımlar yapıların kimliğini bozmakta ve geri dönülemez zararlar vermektedirler. $\mathrm{Bu}$ yapıların en kısa zamanda onarılarak kırsal alanda alternatif bir turizm merkezi olarak ilçe ekonomisine kazandırılabilir. Böylelikle kırsaldan göçler de önlenmiş olur. Gazipaşa bölgesi için tescilsiz yapıların tescillenerek koruma altına alınması ve sonrasında onarılıp zarar vermeyecek şekilde işlevlendirilerek kullanılması gelecek kuşaklara birer mirasımız olacaktır. Böylece yapılan çalışmalar belgeleme çalışması olmaktan çıkıp bir adım öteye gidebilecektir.

\section{Yazarın Notu}

Ali TEPE evi sahipleri Meral Tepe ve Ali Tarık Tepe'ye, Medrese Hocası Halil Ağa'nın 2. Kuşak torunu Gürsel Öğüt'e, Kâtip Mustafa Efendi'nin torunu Fuat Uysal'a yardımlarından ve verdikleri bilgilerden dolayı, arkadaşım Emre Özdemir'e İHA ile fotoğraf çekimleri için teşekkürlerimi sunarım.

\section{Mali Destek Bildirimi (Funding)}

Bu çalışma Dr. Öğr. Üyesi Nacide Öter yürütücülüğünde Dr. Nisa Y. Erkovan'ın araştırmacı olarak katıldığ 1 Alanya Alaaddin Keykubat Üniversitesi Bilimsel Araştırma Projelerini Destekleme Birimi tarafından "Gazipaşa Evleri” adı ile Bilimsel Araştırma Projesi olarak 2018 yılında desteklenmiştir. 


\section{KAYNAKÇA}

Akış A. (1997). Gazipaşa'nın İklimi. Yayımlanmamış Yüksek Lisans Tezi. Selçuk Üniversitesi Sosyal Bilimler Enstitüsü, Konya 1997.

Antalya Valiliği İl Kültür ve Turizm ve Turizm Müdürlüğü (2010). Dünden bugüne Antalya. Cilt 1. Antalya 2010.

Aran K. (2000). Barınaktan Öte Anadolu Kır Yapıları. İstanbul 2000.

Eldem S. H. (1954). Türk Evi Plan Tipleri. İstanbul. 1954.

Gazel A. A. (2007). "Osmanlı'dan Cumhuriyet'e Gazipaşa'nın İdari Durumuna Kısa Bir Bakış”. 20. yüzyllda Antalya Seтроzyuтu 22-25 Kasim 2007 II (2007) 700-712.

Güngör Ş. \& Bozyiğit R (2013). "Gazipaşa İlçesi’nde (Antalya) Köy Yerleşmeleri”. Marmara Coğrafya Dergisi 0/23 (2013) 267-292.

Güngör Ş. (2010). Gazipaşa İlçesi'nin (Antalya) Coğrafi Etüdü. Yayımlanmamış Doktora Tezi. Selçuk Üniversitesi Eğitim Bilimleri, Konya 2010.

Kavas K. R. (2012). "Türk Konut Mimarisinde Tarihsel Süreklilikler: Orta Asya ve Anadolu”. Belleten LXXVI (2012) 503-538.

Köse A. (2005). "Türkiye'de Geleneksel Kırsal Konut Planlarında Göçebe Türk Kültürü İzleri”. Afyon Kocatepe Üniversitesi Sosyal Bilimler Dergisi 7/2 (2005) 158-191.

Kuban D. (1995). Türk 'Hayat'll Evi. İstanbul 1995.

Kuban D. (2017). Türk Ahşap Konut Mimarisi. İstanbul $2017^{2}$.

Küçükerman Ö. \& Güner Ş. (1995). Anadolu Mirasında Türk Evleri. İstanbul 1995.

Yıldız A. (2009). Dünden Bugüne Gazipaşa Tarihi (Selene-Sallune-Selinus-Selinti-Gazipaşa). Antalya 2009. 
